\title{
Analisis Struktur Komunitas Kepiting di Kawasan Mangrove Stasiun Kelautan Universitas Riau Kelurahan Purnama Kota Dumai Provinsi Riau
}

\author{
Analysis of the Kepiting Community Structure in Mangrove Area \\ Marine Station Riau University of Purnama Village, \\ Dumai City, Riau Province
}

\author{
Fenti Rozanda ${ }^{1 *}$, Aras Mulyadi $^{2}$, Syafruddin Nasution $^{2}$ \\ 'Mahasiswa Fakultas Perikanan dan Kelautan, Universitas Riau \\ ${ }^{2}$ Dosen Fakultas Perikanan dan Kelautan, Universitas Riau \\ *Email: rozandafenti@gmail.com
}

\begin{abstract}
Abstrak
Diterima

Penelitian ini dilakukan pada bulan Januari 2019 di kawasan mangrove Desa

11 Mei 2020

Purnama Kota Dumai Provinsi Riau. Tujuan penelitian ini adalah untuk mengetahui struktur komunitas rajungan yang meliputi jenis, kelimpahan, pola sebaran rajungan, keanekaragaman jenis ( $\left.\mathrm{H}^{\prime}\right)$, keseragaman jenis $(\mathrm{E})$, dan dominansi jenis (C) kepiting. Metode yang digunakan dalam penelitian ini

Disetujui adalah metode survei. Terdapat tiga stasiun pengamatan dengan masing-masing tiga transek pada setiap stasiun, pada setiap jalur transek terdapat plot bujur sangkar dengan ukuran $5 \times 5 \mathrm{~m}^{2}$. Pengambilan sampel kepiting dilakukan secara kuantitatif dan kualitatif. Berdasarkan hasil penelitian diketahui bahwa jenis kepiting yang teridentifikasi di daerah penelitian adalah Sesarma reticulatum, $S$. guttatum, Uca dussumieri, U. rosea, U. vocans, Cardisoma carnifex, dan Clistocoeloma merguinse. Selanjutnya kelimpahan rajungan yang diperoleh berkisar antara 1560-2040 Ind / Ha dengan pola sebaran klaster. Nilai rata-rata keanekaragaman jenis $\left(\mathrm{H}^{\prime}\right)$ menunjukkan keanekaragaman sedang, keseragaman (E) menunjukkan keseragaman jenis tinggi, dan nilai dominansi jenis (C) menunjukkan tidak ada jenis yang mendominasi.
\end{abstract}

Kata kunci: Struktur Komunitas, Kepiting, Mangrove, Dumai.

\begin{abstract}
This research was conducted in January 2019 in the mangrove area of Purnama Village, Dumai City, Riau Province. The purpose of this study was to determine the crab community structure which includes the type, abundance, crab distribution patterns, species diversity $\left(\mathrm{H}^{\prime}\right)$, species uniformity $(\mathrm{E})$, and species dominance $(\mathrm{C})$ crabs. The method used in this study is a survey method. There are three observation stations with each of the three transects at each station, on each transect line there is a square plot with a size of $5 \times 5 \mathrm{~m}^{2}$. Crab sampling is done quantitatively and qualitatively. Based on the results of the study it was found that the species of crabs identified at the area of the research were Sesarma reticulatum, S. guttatum, Uca dussumieri, U. rosea, U. vocans, Cardisoma carnifex, and Clistocoeloma merguinse. Furthermore, the abundance of crabs obtained is between 1560-2040 Ind / Ha with cluster distribution patterns. The average value of species diversity $\left(\mathrm{H}^{\prime}\right)$ indicates moderate diversity, uniformity (E) indicates high species uniformity, and species dominance value $(\mathrm{C})$ indicates no dominating species.
\end{abstract}

Keyword: Community Structure, Crab, Mangrove, Dumai 


\section{Pendahuluan}

Seluruh fauna yang hidup di dalam ekosistem pesisir mempunyai peranan yang penting dalam menjaga keseimbangan ekologi. Sekian banyak fauna yang hidup terdapat beberapa kelompok kunci (keystone species) yang memegang peranan yang sangat penting. Salah satu kelompok tersebut adalah kepiting yang hidup di dalam ekosistem mangrove. Kepiting dianggap sebagai keystone species di kawasan pesisir karena setiap aktivitasnya mempunyai pengaruh utama pada berbagai proses ekosistem. Peran kepiting di dalam ekosistem diantaranya membantu mengkonversi nutrien dan mempertinggi mineralisasi, meningkatkan distribusi oksigen di dalam tanah, membantu daur hidup karbon, serta tempat penyedia makanan alami bagi berbagai jenis biota perairan (Prianto, 2007).

Struktur komunitas merupakan suatu konsep yang mempelajari susunan atau komposisi spesies dan kelimpahan dalam suatu komunitas. Pengkajian struktur komunitas kepiting sering digunakan untuk mengindikasikan kestabilan lingkungan, hal ini disebabkan oleh sifatnya yang relatif menetap, mempunyai masa hidup yang relatif lama, mampu beradaptasi pada berbagai tekanan lingkungan, serta mempunyai peranan penting dalam siklus nutrien. Perubahan kualitas air dan kondisi substrat sangat mempengaruhi kelimpahan dan keanekaragaman kepiting. Analisis struktur komunitas kepiting dapat memberikan gambaran tentang keadaan terganggu atau tidaknya suatu ekosistem perairan.

Penelitian terdahulu berkaitan yang pernah dilakukan di kawasan ekosistem mangrove Kelurahan Purnama Dumai ini yaitu: Struktur dan Keragaman Komunitas Kepiting oleh Hamidy (2008). Berdasarkan hasil penelitian tersebut didapatkan data bahwa terdapat 10 jenis yang ditemukan diantaranya berasal dari famili Ocypodidae, Grapsidae, Gecarcinidae, dan Portunidae.

Kelompok kepiting yang hidup di ekosistem mangrove Kelurahan Purnama Dumai ini kurang terdata dengan baik dimana sedikitnya penelitian dan publikasi tentang keberadaan kepiting di lokasi ini. Pentingnya pengkajian keberadaan kelompok kepiting mengingat fungsinya terhadap ekosistem serta sebagai ilmu pengetahuan keanekaragaman hayati laut dirasa perlu untuk melakukan penelitian terkait informasi tentang kelompok kepiting. Setelah hampir satu dekade semenjak dilakukan penelitian tentang kepiting oleh Hamidy (2008) di kawasan ekosistem mangrove Kelurahan Purnama Dumai, serta pentingnya peran kepiting yang merupakan salah satu komunitas dari makrozoobenthos di ekosistem mangrove maka perlu dilakukan penelitian yang kepada kelompok kepiting yang berada di ekosistem mangrove Kelurahan Purnama Dumai.

Tujuan Penelitian ini adalah untuk mengetahui struktur komunitas yang meliputi: Jenis, kelimpahan, pola sebaran, indeks keragaman (H'), keseragaman (E), dan dominansi jenis (C) kepiting di kawasan ekosistem mangrove Stasiun Kelautan Universitas Riau Kelurahan Purnama Provinsi Riau.

\section{Bahan dan Metode}

\subsection{Waktu dan Tempat}

Penelitian ini telah dilaksanakan pada bulan Januari 2019. Pengambilan sampel biota serta pengukuran parameter kualitas air dilakukan di kawasan ekosistem mangrove Stasiun Kelautan Kelurahan Purnama Kota Dumai Provinsi Riau. Sementara tahap identifikasi dan analisis dilakukan di Laboratorium Biologi Laut dan Laboratorium Kimia Laut Jurusan Ilmu Kelautan, Fakultas Perikanan dan Kelautan Universitas Riau. Pengambilan sampel dilakukan pada saat air laut surut dan dilakukan dengan cara purposive sampling berdasarkan karakteristik kawasan dan lokasi pengamatan yang berbeda. Daerah penelitian dibagi atas tiga stasiun (Gambar 1).

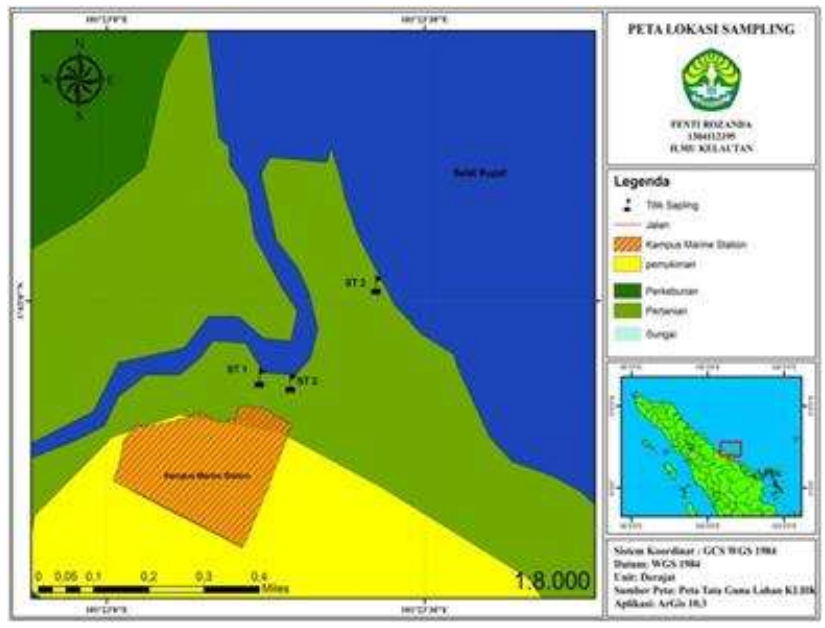

Gambar 1. Peta Lokasi Penelitian 
a) Stasiun I berada di hutan mangrove di tepi aliran sungai Mesjid.

b) Stasiun II berada di hutan mangove berada sekitar $300 \mathrm{~m}$ ke arah timur dari muara sungai Mesjid.

c) Stasiun III berada di di hutan mangove yang menghadap ke perairan Selat Rupat.

Masing-masing stasiun memiliki 3 (tiga) transek dan setiap transek memiliki 3 (tiga) plot yang berukuran $5 \mathrm{~m} \times 5 \mathrm{~m}$. Metoda ini dipilih berdasarkan pertimbangan yaitu diharapkan dengan ukuran yang lebih luas kemungkinan untuk menjumpai kepiting lebih besar mengingat kepiting aktif pada saat surut. Kepiting yang berada pada plot di permukaan substrat diambil dengan tangan (hand picking) dan kepiting yang terdapat di dalam lubang diambil dengan cara menggali lubang tersebut dengan menggunakan sekop sampai kedalaman 10 cm. Metoda pengambilan sampel ini diadopsi dari cara yang digunakan oleh Sasekumar dalam Suryono (2006). Selanjutnya pengambilan sampel secara kualitatif bertujuan untuk inventarisasi jenis kepiting yang berada di ekosistem mangrove. Cara kerja untuk mendapatkan sampel ini yaitu dengan menyisir lokasi penelitian untuk mengumpulkan sampel kepiting dengan cara koleksi bebas (free collections), sampel kepiting yang dijumpai diambil untuk dapat diidentifikasi jenisnya.

\subsection{Prosedur Penelitian}

Pengambilan sampel sedimen bertujuan untuk mengetahui tipe substrat dan analisis bahan organik sedimen pada lokasi penelitian. Pengambilan sampel sedimen dilakukan pada lokasi yang sama dengan pengambilan sampel kepiting. Pengambilan sampel dilakukan dengan menggunakan pipa paralon dengan diameter $10 \mathrm{~cm}$. Sampel sedimen diambil dengan menancapkan pipa paralon ke dalam substrat sampai kedalaman $10 \mathrm{~cm}$. Pengambilan sampel sedimen dilakukan pada setiap titik sampling. Sampel sedimen yang diambil \pm 500 gram, kemudian sampel dimasukkan ke dalam kantong plastik dan diberi label. Sampel sedimen yang sudah diambil sebanyak 500 gram berat basah kemudian diambil $100 \mathrm{~g}$ untuk analisis jenis sedimen berat basah (Rifardi, 2008), kemudian diambil $50 \mathrm{~g}$ untuk analisis bahan organik (Mucha et al., 2003).

Sampel kepiting yang telah didapat dilakukan pengidentifikasian dengan mengamati ciri-ciri fisik untuk menggunakan buku identifikasi menurut Gosner (1971); Morton (1990) serta jurnal-jurnal literatur terkait. Kelimpahan adalah jumlah individu per satuan luas (Odum dalam Hamidy, 2008) dengan formulasi sebagai berikut:

Keterangan :

$$
\mathrm{Di}=\frac{n i}{A}
$$

$$
\begin{aligned}
& \mathrm{Di}=\text { Kelimpahan }\left(\mathrm{jumlah} \text { ind } / \mathrm{m}^{2}\right) \\
& \mathrm{ni}=\text { Jumlah individu dari jenis ke-i } \\
& \mathrm{A}=\text { Luas area pengambilan }
\end{aligned}
$$

Keragaman jenis kepiting dilokasi penelitian dihitung dengan Indeks Keragaman Shannon - Wiener dalam Hamidy (2008) sebagai berikut :

Keterangan :

$$
H^{\prime}=\sum_{i=1}^{s} \text { pi log2pi }
$$

$$
\begin{aligned}
& \mathrm{H}^{\prime}=\text { Indeks Keragaman Shannon-Wiener } \\
& \text { pi }=\text { ni/N } \\
& \text { ni }=\text { Jumlah individu jenis ke-i } \\
& \mathrm{N}=\text { Jumlah total individu }
\end{aligned}
$$

Nilai tolak ukur untuk keragaman jenis, yaitu:

$$
\begin{aligned}
\mathrm{H}^{\prime}<1,0 & =\begin{array}{l}
\text { Keragaman rendah, produktivitas sangat rendah, sebagai indikasi adanya tekanan yang } \\
\text { berat dan ekosistem tidak stabil. }
\end{array} \\
1,0 \leq \mathrm{H}^{\prime} \leq 3,322= & \begin{array}{l}
\text { Keragaman sedang, produktivitas cukup, kondisi ekosistem cukup seimbang, tekanan } \\
\text { ekologis sedang }
\end{array} \\
= & \begin{array}{l}
\text { Kearagaman tinggi stabilitas ekosistem mantap, produktivitas tinggi, tahan terhadap } \\
\text { tekanan ekologis }
\end{array}
\end{aligned}
$$

Rumus keseragaman jenis kepiting dihitung dengan menggunakan rumus menurut Krebs (2014), yaitu:

Keterangan :

$$
E=\frac{H^{\prime}}{H^{\prime} \max }=\frac{H^{\prime}}{\log 2 S}
$$

$\mathrm{E}=$ Indeks Keseragaman

$\mathrm{H}^{\prime}=$ Indeks Keanekaragaman Shannon-Wiener

$\mathrm{S}=$ Jumlah jenis 
Kategori indeks keseragaman yaitu :

$0<\mathrm{E} \leq 0,5 \quad=$ Kondisi tertekan dan keseragaman rendah.

$0,5<\mathrm{E} \leq 0,75=$ Kondisi kurang stabil dan keseragaman sedang.

$0,75<\mathrm{E} \leq 1,0 \quad=$ Kondisi stabil dan keseragaman tinggi.

Metode penghitungan yang digunakan adalah rumus Dominansi Simpsons dalam Hamidy (2008) :

$$
\mathrm{C}=\Sigma\left(\frac{n i}{N}\right)^{2}
$$

Keterangan :

$$
\begin{aligned}
& \mathrm{C}=\text { Indeks Dominasi } \\
& \text { ni }=\text { Jumlah individu jenis ke-i } \\
& \mathrm{N}=\text { Jumlah total individu }
\end{aligned}
$$

Kriteria Dominasi jenis adalah :

$$
0<\mathrm{C} \leq 0,5=\text { Tidak ada jenis yang mendominasi }
$$

$0,5>\mathrm{C}>1=$ Terdapat jenis yang mendominasi

Pola sebaran jenis kepiting dihitung menurut Krebs dalam Saputra et al. (2020):

Keterangan :

$$
\mathbf{I d}=\mathbf{n}\left\{\frac{\sum X_{i}^{n}-\sum X_{i}}{\left(\sum X_{i}\right)^{2}-\sum X_{i}}\right\}=\frac{n\left(\sum x 2-n\right)}{N(N-1)}
$$

$$
\begin{array}{ll}
\mathrm{Id} & =\text { Indeks Dispersi Morisita } \\
\mathrm{n} & =\text { Jumlah plot } \\
\mathrm{N} & =\text { Jumlah total individu } \\
\Sigma \mathrm{x}^{2} & =\text { Jumlah individu pada setiap plot }
\end{array}
$$

Kriteria pola sebaran jenis menurut Krebs dalam Saputra et al. (2020) :

$$
\begin{array}{ll}
\text { ID }>0 & \text { : Menunjukkan pola sebaran mengelompok / Clumped (C) } \\
\text { ID }=0 & \text { : Menunjukkan pola sebaran acak / Random }(\mathrm{R}) \\
\text { ID }<0 & \text { : Menunjukkan pola sebaran teratur / Uniform }(\mathrm{U})
\end{array}
$$

Analisis uji Anova One Way dilakukan menggunakan software Statistical Package For Social Science (SPSS) untuk mengetahui perbedaan kelimpahan kepiting antar stasiun dan dilakukan uji lanjut LSD jika terdapat perbedaan yang signifikan.

\section{Hasil dan Pembahasan}

\subsection{Keadaan Umum Daerah Penelitian}

Kota Dumai terletak di pesisir timur pulau Sumatera berhadapan dengan pulau Rupat dan Selat Malaka. Kota Dumai terdiri dari 5 (lima) kecamatan yaitu Kecamatan Bukit Kapur, Kecamatan Medang Kampai, Kecamatan Sungai Sembilan, Kecamatan Dumai Barat, dan Kecamatan Dumai Timur. Kelurahan Purnama merupakan salah satu daerah dari Kecamatan Dumai Barat Kota Dumai Provinsi Riau. Kelurahan Purnama secara geografis terletak pada posisi 101027'07" - 101030'07” BT dan 1036'09” - 1041'10” LU. Batas-batas Kelurahan Purnama yaitu sebelah utara berbatasan dengan Selat Rupat, sebelah selatan berbatasan dengan Mekar Sari, sebelah timur berbatasan dengan Pangkalan Sesai, dan sebelah Barat berbatasan dengan Bagan Keladi.

Daerah yang menjadi objek penelitian terletak di Stasiun Kelautan Kelurahan Purnama Kecamatan Dumai Barat Kota Dumai Provinsi Riau. Perairan pantai Purnama Dumai dikelilingi oleh beberapa pulau yakni Pulau Rupat, Pulau Payung, Pulau Rempang, Pulau Baru, Pulau Mantek, Pulau Mampu dan Pulau Ketam. Dengan demikian perairan ini memiliki ombak yang relatif kecil karena angin yang bertiup terhalang oleh pulau-pulau tersebut sehingga kondisi perairan bisa dikatakan relatif tenang.

Disekitar perairan ditumbuhi oleh vegetasi mangrove. Luas kawasan mangrove di Stasiun Kelautan Dumai ini \pm 23 ha dari total keseluruhan, dengan kondisi masih tergolong baik. Sebanyak 22 jenis mangrove yang teridentifikasi di kawasan ini yang sebagian besar dari jenis itu merupakan jenis yang umum dijumpai di Indonesia. Jenis mangrove dominan di kawasan ini berasal dari family Rhizoporaceae (Rhizopora apiculata, $\mathrm{R}$. mucronata, Bruguiera gymnorhiza), family Meliaceae (Xylocarpus spp.), family Avicenniaceae (Avicennia alba, A. marina), family Euphorbiaceae (Excoecaria agalorca), family Combretaceae (Lumnitzera littorea), family Arecaceae (Nypa fructicans), family Lythraceae (Sonneratia spp.) dengan kerapatan kurang (Mulyadi, 2010).

Keberadaan hutan mangrove memberikan kontribusi yang sangat besar terhadap kelangsungan hidup organisme perairan pesisir maupun pantai. Adapun tipe sedimen yang terdapat di kawasan perairan ini jika 
dilihat secara visual yaitu lumpur. Dominasi lumpur Keberadaan hutan mangrove memberikan kontribusi yang sangat besar terhadap kelangsungan hidup organisme perairan pesisir maupun pantai. Adapun tipe sedimen yang terdapat disebabkan antara lain oleh karena secara geografis dikelilingi pulau-pulau, serta kawasan ini terletak tidak jauh dari muara Sungai Mesjid sehingga terbawanya bahan-bahan organik dan fraksi halus menyebabkan sedimen dari darat terurai dalam bentuk berbagai partikel.

\subsection{Jenis dan Kelimpahan Kepiting}

Kepiting yang teridentifikasi di kawasan ekosistem mangrove Stasiun Kelautan terdapat 7 (tujuh) spesies yang termasuk ke dalam 4 (empat) Family yaitu Sesarmidae, Ocypodidae, Gecarcinidae dan Grapsidae (Tabel 1). Biasanya kepiting yang sering ditemukan di mangrove adalah jenis penggali dari genus Clistocoeloma, Macrophthalmus, Metaplax, Ilyoplax, Sesarma, dan Uca (Suryono, 2006) yang mana tiga diantaranya ditemukan di lokasi penelitian yaitu genus Clistocoeloma, Sesarma, dan Uca kerena substrat dasar perairan daerah penelitian adalah berlumpur sehingga sangat mudah untuk dibuat lubang.

Tabel 1. Jenis-Jenis Kepiting di Lokasi Penelitian

\begin{tabular}{clll}
\hline Klas & \multicolumn{1}{c}{ Famili } & \multicolumn{1}{c}{ Genus } & \multicolumn{1}{c}{ Spesies } \\
\hline & Sesarmidae & Sesarma & Sesarma guttatum \\
& & & S. reticulatum \\
Crustacea & Ocypodidae & Uca & Uca dussumieri \\
& & & U. rosea \\
& & U. vocans \\
& Gecarcinidae & Cardisoma & Cardisoma carnifex \\
& Grapsidae & Clistocoeloma & Clistocoeloma mergunse \\
\hline
\end{tabular}

Kepiting dari family Sesarmidae banyak terdapat pada lokasi penelitian, terutama jenis $S$. reticulatum yang ditemukan hampir di setiap plot penelitian. Hal ini sesuai dengan pendapat yang dikemukakan Hamidy (2008) bahwa kepiting Sesarmid khususnya dapat hidup pada permukaan sedimen, atau pohon mangrove, dapat mentoleransi salinitas dengan rentang lebar, yang menyebabkan dominannya kepiting ini di hutan mangrove. Selanjutnya, Robertson dalam Hamidy (2008) juga menjelaskan bahwa salah satu kelompok kepiting yang cukup berperan penting di hutan mangrove adalah Sesarma.

Tabel 2. Rata-Rata Kelimpahan Kepiting di Lokasi Penelitian.

\begin{tabular}{ccccccc}
\hline & \multicolumn{3}{c}{ Kelimpahan (Ind/ha) } & & \multirow{2}{*}{ Rata-Rata } & \multirow{2}{*}{ Kelimpahan Relatif (\%) } \\
\cline { 2 - 4 } Stasiun & I & II & III & & 720 & 40 \\
Sreticulatum & 840 & 660 & 660 & 366 & 20 \\
S. guttatum & 440 & 350 & 310 & 110 & 6 \\
Uca dussumieri & 170 & 80 & 80 & 130 & 11 \\
U. rosea & 0 & 260 & 130 & 203 & 4 \\
U. vocans & 130 & 350 & 130 & 83 & 9 \\
Cardisoma carnifex & 0 & 170 & 80 & 156 & 100 \\
Clistocoeloma merguinse & 130 & 170 & 170 & 1770 & 7 \\
\hline Jumlah per Stasiun & 1710 & 2040 & 1560 & & & \\
\hline
\end{tabular}

Nilai kelimpahan kepiting dapat dilihat pada Tabel 2. Kelimpahan kepiting yang telah diamati pada setiap stasiun memiliki nilai yang berbeda-beda. Kisaran nilai kelimpahan kepiting yang terdapat pada setiap stasiun penelitian yaitu 1560 - 2040 Ind/ha, dimana nilai kelimpahan tertinggi terdapat pada stasiun II yaitu 2040 Ind/ha dan nilai kelimpahan terendah terdapat pada stasiun III yaitu dengan nilai kelimpahan 1560 Ind/ha. Rata-rata kelimpahan kepiting pada seluruh stasiun penelitian yang terdapat di kawasan ekosistem mangrove Stasiun Kelautan Kelurahan Purnama yaitu 1770 Ind/ha. Kelimpahan relatif kepiting pada setiap stasiun penelitian dijumpai spesies yang memiliki tingkat kelimpahan relatif tertinggi yaitu Sesarma reticulatum dengan kelimpahan relatif $48,7 \%$. Gambaran tingkat kelimpahan jenis pada stasiun dapat disebabkan oleh jenis yang melimpah mampu beradaptasi dengan baik pada lingkungannya, seperti hasil kelimpahan rata-rata tertinggi pada penelitian ini yaitu dari jenis Sesarma reticulatum yang bisa dijumpai pada setiap titik sampling, hal ini juga dikemukakan oleh Rauf et al. (2016) bahwa kemampuan adaptasi dari famili Grapsidae dan Sesarmidae yaitu mampu hidup di lingkungan yang ekstrim serta mudah beradaptasi.

Secara umum kelimpahan kepiting dipengaruhi oleh banyak faktor diantaranya jenis substrat, habitat tempat hidup, stabilitas lingkungan, produktivitas, kompetisi dan sumber makanan (Wahab et al., 2016). Sesarmidae dan Ocypodidae merupakan dua family yang besar hasil rata-rata kelimpahan jenisnya pada penelitian ini. Hasil ini sesuai dengan pernyataan Pratiwi dan Widyastuti (2013) yang menyatakan bahwa kepiting dari family Grapsidae, Sesarmidae dan Ocypodidae merupakan jenis kepiting yang biasanya banyak ditemukan di daerah 
mangrove, hal tersebut terjadi karena adanya pemilihan habitat yang mengakibatkan jenis tertentu dapat ditemukan di satu lokasi sedangkan jenis tersebut tidak dijumpai di lokasi lain.

\subsection{Indeks Keragaman (H'), Keseragaman (E), dan Dominansi Jenis (C)}

Nilai indeks keragaman (H') untuk stasiun I nilai rata-ratanya yaitu 1,8944 stasiun II nilai keragamannya memiliki nilai rata-rata 2,3193 dan stasiun III memiliki keragaman rata-rata 2,2154. Berdasarkan kriteria nilai tolak ukur yang dikemukakan oleh Hamidy (2008) dapat diketahui bahwa setiap stasiun penelitian umumnya memiliki indeks keragaman $1,0 \leq \mathrm{H}^{\prime} \leq 3,322$ sehingga keragaman dikategorikan sedang. Menurut Suryono (2006), yang mempengaruhi nilai keragaman kepiting yang tergolong sedang pada tiap lokasi adalah beberapa jenis kepiting yang mempunyai kecenderungan menetap pada pohon tertentu dan tidak mampu beradaptasi dengan baik terhadap perubahan lingkungan. Rahayu et al. (2016) menyatakan bahwa banyaknya jenis dalam suatu komunitas dan kelimpahan dari tiap jenis akan mempengaruhi keragaman di suatu ekosistem. Keragaman dalam suatu ekosistem akan berkurang jika semakin sedikit jumlah jenis dan adanya variasi jumlah individu dari suatu jenis atau ada beberapa jenis yang memiliki jumlah individu yang lebih besar.

Nilai rata-rata indeks keseragaman (E) yang didapatkan pada stasiun I yaitu 0,8159 stasiun II 0,8984 dan stasiun III dengan nilai rata-rata keseragaman 0,8625. Mengacu kepada nilai tolak ukur keseragaman oleh Krebs (2014) dapat diketahui bahwa setiap stasiun penelitian umumnya memiliki indeks keseragaman keseragaman $0,75<\mathrm{E} \leq 1,0$ sehingga dikategorikan keseragaman tinggi. Redjeki et al. (2016) menyatakan bahwa kesergaman yang tinggi menunjukkan tidak terdapat jenis yang lebih dominan dari jenis-jenis lainnya, sehingga jenis kepitingnya dapat beranekaragam atau bervariasi.

Nilai indeks dominansi (C) yang didapatkan pada stasiun I memiliki nilai rata-rata 0,3305 selanjutnya untuk stasiun II memiliki nilai rata-rata 0,2353 dan stasiun III dengan nilai rata-rata yaitu 0,2723. Pada setiap stasiun penelitian didapatkan bahwa tidak ada jenis yang mendominasi.. Menurut Odum dalam Bahari et al. (2020) bahwa ketika nilai indeks dominansi (C) mendekati nol maka tidak ada jenis yang mendominasi. Indeks dominansi pada penelitian ini tidak ditemukan spesies mendominansi. Natania et al. (2017) menjelaskan tidak adanya dominansi dan keseragaman spesies yang tinggi di lokasi penelitian menggambarkan kondisi ekosistem yang tergolong stabil.

Nilai indeks keragaman, keseragaman, dan dominansi berkaitan dengan kompetisi ruang dan makanan, habitat, kebiasaan makan dan parameter lingkungan. Krebs dalam Redjeki et al., (2016) menambahkan, tekanan lingkungan seperti ada atau tidaknya gangguan dari aktivitas manusia dan tingkat sedimentasi akan mempengaruhi perolehan kelimpahan individu masing-masing jenis dan nilai indeks keanekaragaman, keseragaman, dominansi dalam komunitas.

\subsection{Pola Sebaran Kepiting}

Nilai Indeks Morisita (Id) kepiting pada stasiun I adalah 1,0 stasiun II yaitu 1,02 dan stasiun III yaitu 1,08. Pola sebaran yang ditunjukkan kelompok kepiting yang berada di lokasi penelitian yaitu dengan pola sebaran mengelompok. Jenis diatom yang ditemukan di perairan Meral dapat dilihat pada Tabel 3.

Tabel 3. Pola Sebaran Kepiting di Lokasi Penelitian

\begin{tabular}{ccl}
\hline Stasiun & Id & Pola sebaran \\
\hline I & 1,0 & Mengelompok \\
II & 1,02 & Mengelompok \\
III & 1,08 & Mengelompok \\
\hline
\end{tabular}

Struktur suatu komunitas alamiah bergantung pada cara biota tersebut menyebar di dalamnya. Pola penyebaran bergantung pada sifat-kimia lingkungan maupun keistimewaan biologis organisme itu sendiri. Dari hasil penelitian ditunjukkan bahwa kepiting yang berada di lokasi penelitian menunjukkan sebaran mengelompok. Penyebaran secara mengelompok atau berumpun, artinya individu-individu selalu dalam kelompok dan sangat jarang terlihat sendiri secara berpisah (Michael dalam Redjeki et al., 2016).

Pola sebaran biota dapat diakibatkan oleh adanya preferensi habitat oleh biota itu sendiri. Pola penyebaran mengelompok dengan tingkat pengelompokkan yang bermacam-macam merupakan bentuk penyebaran yang paling umum terjadi, karena individu- individu dalam populasi cenderung membentuk kelompok dalam berbagai ukuran. Penyebaran mengelompok akan meningkatkan persaingan antar individu dalam menanggapi perubahan habitat dan dalam mendapatkan makanan serta ruang gerak.

\section{Kesimpulan}

Jenis kepiting yang teridentifikasi di kawasan ekosistem mangrove Stasiun Kelautan Kelurahan Purnama yaitu Sesarma reticulatum, S. guttatum, Uca dussumieri, U. rosea, U. vocans, Cardisoma carnifex, dan Clistocoeloma merguinse. Kelimpahan tertinggi berada pada lokasi yang berdekatan dengan muara sungai dan Sesarma reticulatum merupakan spesies yang paling tinggi nilai kelimpahan jenisnya. Sedangkan pola sebaran 
yang ditunjukkan oleh kelompok kepiting di lokasi penelitian yaitu mengelompok. Keragaman jenis pada penelitian ini diketahui sedang dengan keseragaman yang tinggi serta tidak adanya jenis yang mendominasi di lokasi penelitian.

\section{Referensi}

Bahari, S., S. Nasution, dan S.H. Siregar. 2020. Community Structure of Gastropod (Mollusca) in the Mangrove Ecosystem of Purnama, Dumai City, Riau Province. Asian Journal of Aquatic Sciences, 3(2): 111-122

Gosner, P.S. 1971. Guide Identification of Marine and Estuarine Intervertebrate. A Wiley Inter Science Publishing. New York.

Hamidy, R. 2008. Struktur dan Keragaman Komunitas Kepiting di Kawasan Hutan Mangrove Stasiun Kelautan Universitas Riau Desa Purnama Dumai. Journal of Environmental Science. 4(2): 2010.

Krebs, J. C. 2014. Ecological Methodology. 3nd Edition. Published by Addison-Welsey.

Morton, J. 1990. The Shore Ecology of The Tropical Pasific. UNESCO.

Mucha, A. P, M, T. S. D. Vasconcelos and A. A. Bordalo. 2003. Macrobenthic Community in The Douro Estuary Relation With Trace Metals and Natural Sediment Characteristic. Journal of Environmental Pollution. 121: 160-180.

Mulyadi, A. 2010. Mangrove di Kampus Universitas Riau Dumai. Pekabaru. UR press. 49 hlm

Natania, T., N.E. Herliany, dan A.B. Kusuma. 2017. Struktur Komunitas Kepiting Biola (Uca spp.) di Ekosistem Mangrove Desa Kahyapu Pulau Enggano. Jurnal Enggano. 2(1): 11-24.

Pratiwi R. dan E. Widyastuti. 2013. Pola Sebaran dan Zonasi Krustasea di Hutan Bakau Perairan Teluk Lampung. Zoo Indonesia. 22(1): 11-21.

Prianto, E. 2007. Peran Kepiting Sebagai Spesies Kunci (Keystone Spesies) pada Ekosistem Mangrove. Prosiding Forum Perairan Umum Indonesia IV. Balai Riset Perikanan Perairan Umum. Banyuasin.

Rauf, A., A. Kasim, dan A. Ramadhan. 2016. Struktur Komunitas Kepiting di Hutan Mangrove Kecamatan Toribulu Kabupaten Parigi Moutong dan Pemanfaatannya Sebagai Media Pembelajaran Biologi. Jurnal Sains dan Teknologi Tadulako. 5(1): 78-85.

Redjeki, S., M. Arif, R. Hartati, dan L.K. Pinandita. 2016. Kepadatan dan Persebaran Kepiting (Brachyura) di Ekosistem Hutan Mangrove Segara Anakan Cilacap. Jurnal Kelautan Tropis. 20(2): 131-139.

Rifardi. 2008. Tekstur Sampling dan Analisis Sedimen. Unri Press. Pekanbaru. 101 hlm

Saputra, R., Zulkifli, dan S. Nasution. 2020. Diversity and Mollusca Distribution Patterns (gastropoda and Bivalvia) in the North of Poncan Gadang Island, Sibolga City North Sumatera Province. Journal of Coastal and Ocean Sciences, 1(1): $16-24$

Suryono, C.A. 2006. Ekologi Perairan Delta Wulan Demak Jawa Tengah: Distribusi Kepiting (Infra Ordo Brachyura dan Anomura) di Kawasan Mangrove. Jurnal Ilmu Kelautan. 11(4): 210 - 215.

Wahab, I., M. Kawaroe, dan H. Maduppa. 2016. Perbandingan Kelimpahan Makrozoobenthos di Ekosistem Lamun Pada Saat Bulan Purnama dan Perbani di Pulau Panggang Kepulauan Seribu Jakarta. Jurnal Ilmu dan Teknologi Kelautan Tropis. 10(1): 217-229. 